\title{
PELAYANAN KESEHATANDALAM PENDEKATAN KOMUNIKASI ANTARBUDAYA (STUDI FENOMENOLOGI PELAYANAN KESEHATAN DOKTER KEPADA PASIEN DI RSUP H. ADAM MALIK MEDAN)
}

\author{
Rosario Dorothy Simanjuntak \\ Universitas Sumatera Utara \\ rosario_dorothy@yahoo.co.id
}

\begin{abstract}
Abstrak
Penelitian ini bertujuan untuk mengetahui proses pelayanan kesehatan dokter kepada pasien di Instalasi Rawat Jalan RSUP H. Adam Malik dalam pendekatan komunikasi antarbudaya, bagaimana pemahaman dokter dalam berkomunikasi dengan pasiennya yang berbeda budaya dan hambatan komunikasi antarbudaya apa saja yang mempengaruhi pelayanan kesehatan dokter kepada pasien. Metode yang digunakan dalam penelitian ini adalah metode kualitatif dengan sudut pandang fenomenologi. Penelitian dilakukan melalui observasi dan wawancara mendalam kepada 5 orang dokter dan 4 orang pasien di Instalasi Rawat Jalan RSUP H. Adam Malik.Hasil temuan penelitian menunjukkan bahwa masih ditemukan dokter yang sangat terbatas dalam memberikan penjelasan kepada pasien, minim informasi dan terkesan terburu-buru. Karakteristik dokter dan pasien serta faktor situasional turut memberikan pengaruh pada proses pelayanan kesehatan. Hambatan antarbudaya seperti bahasa, pengalaman, hambatan fisik, kompetisi dan hambatan nonverbal merupakan hambatan yang muncul dalam penelitian ini.
\end{abstract}

Kata Kunci:komunikasi antarbudaya, komunikasi kesehatan, pelayanan kesehatan

\begin{abstract}
This study aims to determine the healthcare service process from doctors to patients at Instalasi Rawat Jalan RSUP H. Adam Malik in intercultural communication approach, how the doctors' understanding when communicating with patients from different cultures and what intercultural communication barriers that influence the process. The method used in this research is qualitative method with a phenomenological viewpoint. The research was conducted through observation and in-depth interviews with 5 doctors and 4 patients at Instalasi Rawat Jalan RSUP H. Adam Malik. Research findings indicate that there are still doctors who are very limited in giving explanations to patients, lack of information and appeared to be in hurry. Characteristics of doctors and patients as well as situational factors contribute to the process of this healthcare service. Intercultural barriers such as language, experience, physical barriers, competition and nonverbal barriers are some of the factorsemerged in this study.
\end{abstract}

Keywords: intercultural communication, health communication, health services 


\section{PENDAHULUAN}

Kesehatan adalah kebutuhan penting masyarakat urban saat ini. Komunikasi kesehatan yang melibatkan dokter, pasien dan keluarga adalah komunikasi yang tidak dapat dihindari dalam kegiatankesehatan atau klinikal.Komunikasi kesehatan yang berlangsung positif memberikan dampak penting bagi pasien, dokter dan orang lain. Tidak dapat dipungkiri, hubungan dokter dan pasien tidak selalu harmonis. Terkadang, keduanya bersengketa terkait pelayanan medis. Sengketa antara dokter dan pasien ternyata seringkali disebabkan oleh hal-hal yang sepele, seperti kesalahpahaman atau miskomunikasi. Kita sering mendengar keluhan pasien tentang dokter yang pendiam, tidak sabaran atau tidak mau mendengarkan keluhan pasien sampai tuntas, minim informasi dan sebagainya. Pasti ada alasan mengapa akhirnya muncul persepsi yang memprihatinkan ini.

Sengketa medis lebih sering terjadi karena adanya kesenjangan persepsi antara dokter dan pasien. Pada satu sisi, pasien dan keluarga merasa kurang puas dengan proses atau hasil pengobatan yang dilakukan, sedangkan di sisi lain, dokter dan pihak rumah sakit merasa sudah melakukan pengobatan secara optimal. Sengketa medis ini terjadi karena adanya perbedaan persepsi antara dokter dan pasien mengenai penyakit, adanya ekspektasi yang berlebihan dari pasien terhadapdokter,adanyaperbedaanbahasa,ma knapesan dokterdenganpasien, dan atau ketidaksiapan dokter untuk menjalin komunikasi yang empatik (Berry, 2007: 27).

$$
\text { Berdasarkan data Majelis }
$$

Kehormatan Disiplin Kedokteran Indonesia (MKDKI), dalam kurun waktu 8 tahun, terdapat 193 kasus pengaduan terhadap profesi dokter dari tahun 2005-2013 (https://m.tempo.co). Menurut MKDKI, hal yang paling sering menjadi pokok sengketa adalah kelemahan komunikasi antara dokter dengan pasien atau antara rumah sakit dengan pasien. Cara kita berkomunikasi sebagian besar dipengaruhi oleh kultur, orang-orang dari kultur yang berbeda akan berkomunikasi secara berbeda. Artinya, budaya dan komunikasi tidak dapat dipisahkan karena tidak hanya memutuskan siapa, tentang apa dan bagaimana komunikasi berlangsung, tetapi budaya juga turut menentukan bagaimana orang menyadari pesan, makna yang ia miliki untuk pesan dan kondisi-kondisi untuk mengirim, memperhatikan, dan menafsirkan pesan. Dokter dan pasienperlu menaruh perhatian khusus untuk menjaga jangansampaiperbedaankulturmenghambati nteraksiyang

bermakna,melainkanjustrumenjadisumberun tukmemperkayapengalaman

komunikasi.Jikainginberkomunikasisecaraef ektif, makaperlu memahami danmenghargaiperbedaanini.

Rumah Sakit Umum Pusat Haji Adam Malik (RSUP H. Adam Malik) merupakan salah satu tempat di mana keragaman budaya bertemu dalam dunia medis. Sebagai satu-satunya Rumah Sakit tipe A di Sumatera Utara berdasarkan SK Menkes RI No.2244/Menkes/SK/XI/2011 tanggal 7 November 2011 Tentang Pemberian Izin Operasional Tetap RSUP H. Adam Malik Medan dan SK Menteri Kesehatan

RI No.HK.02.02/MENKES/390/2014 tanggal 17 Oktober 2014 tentang Pedoman Penetapan Rumah Sakit Rujukan Nasional, RSUP H. Adam Malik menjadi pusat rujukan bagi pasien-pasien yang tidak lagi mampu ditangani oleh rumah sakit-rumah sakit yang berada di bawahnya. 
Dari sisi pasien, di sinilah keragaman budaya tersebut berkumpul, pasien yang berasal dari seluruh penjuru Sumatera Utara, yang berasal dari beragam suku dan budaya berkumpul dalam rangka mencari solusi pengobatan yang terbaik. Dari sisi dokter dan tenaga kesehatan, RSUP $\mathrm{H}$. Adam Malik merupakan Rumah Sakit pusat pendidikan di Sumatera Utara. Para tenaga medis di Sumatera Utara, terutama dokter dan perawat, yang sedang menuntut ilmu sesuai kompetensi medisnya masingmasing terpusat di rumah sakit ini, mengaplikasikan ilmu dan pengetahuannya dalam melayani pasien.

Ditambah lagi kehadiran para tenaga medis yang berasal dari luar Sumatera Utara dan luar negeri (seperti Malaysia), menambah keragaman budaya tenaga medis di RSUP H. Adam Malik.Komunikasi kesehatan antara dokter dan pasien yang dulu menganut pola paternalistik dengan dokter pada posisi yang lebih dominan sudah saatnya diubah menjadi setara antara dokter dan pasien. Efektifitas komunikasi yang baik antara kedua belah pihak akan berdampak pada kesehatan yang lebih baik, kenyamanan, kepuasan pada pasien dan penurunan resiko malpraktik, serta perselisihan atau sengketa yang terjadi antara dokter dan pasien.

Berdasarkan uraian di atas, fokus masalah yang peneliti ingin lihat adalah sebagai berikut:

1. Proses pelayanan kesehatan dokter kepada pasien dalam pendekatan komunikasi antarbudaya.

2. Pemahaman dokter dalam berkomunikasi dengan pasiennya yang berbeda budaya.

3. Hambatan-hambatan komunikasi antarbudaya apa saja yang mempengaruhi pelayanan kesehatan dokter kepada pasien.

\section{METODE PENELITIAN}

Metode yang digunakan dalam penelitian ini adalah metode kualitatif dengan sudut pandang fenomenologi. Fenomenologi merupakan cara yang digunakan manusia untuk memahami dunia melalui pengalaman langsung. Fenomenologi berarti membiarkan segala sesuatu menjadi jelas sebagaimana adanya (Littlejohn, 2011: 57).Tradisi fenomenologi menekankan pada proses interpretasi. Fenomenologi secara harfiah berarti penelitian tentang pengalaman sadar, dimana interpretasi mengambil peranan yang penting (Littlejohn, 2011:192).

Peneliti akan mengkaji bagaimana pelayanan kesehatan dokter kepada pasien dalam pendekatan komunikasi antarbudaya berdasarkan aspek-aspek yang ada. Penentuan aspek kajian ini juga berdasarkan pertimbangan pada kemampuan peneliti dalam melaksanakan penelitian.Aspek-aspek tersebut meliputi:

1. Aspek Proses Pelayanan Kesehatan Dokter kepada Pasien

Aspek-aspek yang akan dilihat tentang proses pelayanan adalah:

a. Menciptakan hubungan yang baik dengan pasien di awal komunikasi
b. Durasi waktu melayani/berkonsultasi dengan pasien

c. Evaluasi respon pasien

2. Aspek Pemahaman Dokter dalam berkomunikasi dengan pasien

Aspek-aspek yang akan dilihat tentang pemahaman dokter adalah:

a. Cara menyampaikan pesan

b. Kesamaan makna pesan

3. Aspek hambatan antarbudaya yang mempengaruhi pelayanan kesehatan dokter kepada pasien.

Aspek-aspek yang dilihat tentang hambatan antarbudaya adalah: 
a. Hambatan-hambatan antarbudaya apa saja yang muncul dalam pelayanan kesehatan dokter kepada pasien

b. Bagaimana cara mengatasinya dan apa pengaruhnya terhadap pelayanan kesehatan serta diagnosa penyakit.

Prosedur pemilihan informan peneliti lakukan melalui tahapan observasi terhadap proses pelayanan kesehatan yang terjadi di Instalasi Rawat Jalan RSUP H. Adam Malik. Proses pelayanan kesehatan dari dokter kepada pasien di Instalasi Rawat Jalan RSUP H. Adam Malik melibatkan dokter skrining, dokter co-ass, dokter PPDS, dokter spesialis dan pasien.Sesuai dengan tujuan penelitian maka peneliti menggunakan teknik purposive dalam penentuan informan, yaitu teknik penentuan informan dengan pertimbangan tertentu, misalnya orang tersebut dianggap paling tahu tentang apa yang kita harapkan sehingga akan memudahkan peneliti menjelajahi obyek/situasi sosial yang diteliti (Sugiyono, 2013: 54).

Kriteria informan yang dipilih sesuai dengan tujuan penelitian, yaitu:

1. Dokter yang telah bertugas di Instalasi Rawat Jalan RSUP H. Adam Malik lebih dari 1 tahun.

2. Pasien yang mendapat perawatan atau pelayanan kesehatan di Instalasi Rawat Jalan RSUP H. Adam Malik lebih dari satu kali (bukan pasien baru).

3. Memiliki pengalaman tentang aktivitas komunikasi antarbudaya antara dokter dan pasien selama menjalani proses pengobatan.

4. Bersedia menjadi informan penelitian dan memiliki waktu memberikan informasi yang dibutuhkan untuk kepentingan penelitian.
Berdasarkan uraian diatas, maka yang menjadi informan utama dalam penelitian ini adalah dokter di Instalasi Rawat Jalan RSUP H. Adam Malik dan pasien di Instalasi Rawat Jalan RSUP H. Adam Malik sebagai informan tambahannya. Informan diharapkan memiliki pengalaman tentang aktivitas komunikasi antarbudaya antara dokter dan pasien selama menjalani proses pengobatan. Informan pun dianggap mampu menceritakan kembali pengalaman yang pernah dialaminya.

Informan utama dalam penelitian ini adalah 5 orang dokter di Instalasi Rawat Jalan RSUP H. Adam Malik, yang terdiri dari 1 orang dokter skrining, 2 orang dokter PPDS dan 2 orang dokter spesialis. Informan tambahan adalah 4 orang pasien di Instalasi Rawat Jalan RSUP H. Adam Malik.

Data yang digunakan dalam penelitian ini adalah data primer dan data sekunder. Data primer diperoleh langsung dari informan melalui observasi dan wawancara mendalam. Sedangkan untuk data sekunder diperoleh dengan melakukan studi dokumen.Kegiatan observasi peneliti lakukan mulai bulan Maret-Juli 2016, sejak pra penelitian sampai pada saat berlangsungnya wawancara di Instalasi Rawat Jalan RSUP H. Adam Malik.

Peneliti mengamati proses pelayanan kesehatan yang terjadi di Instalasi Rawat Jalan RSUP H. Adam Malik, berupa rangkaian kegiatan secara menyeluruh yang dilakukan dokter dan pasien mulai saat pertama pasien datang sampai selesai berobat.Wawancara yang dilakukan dalam penelitian ini adalah wawancara mendalam (indepth interview) dengan menggunakan pedoman wawancara.

Analisis data kualitatif di mulai dari analisis berbagai data yang berhasil dikumpulkan peneliti di lapangan, melalui proses berikut ini (Moleong, 2014:249260): 
1. Pemrosesan Satuan

Kegiatan pemrosesan satuan terdiri atas tipologi satuan dan penyusunan satuan. Lincoln dan Guba (Moleong, 2014:249) menamakan satuan itu sebagai satuan informasi yang berfungsi untuk menentukan atau mendefinisikan kategori.Adapun pemrosesan satuan ini peneliti lakukan dengan cara:

a. Analisis data dimulai dengan membuat transkrip hasil wawancara, dengan cara memutar kembali rekaman hasil wawancara, mendengarkan dengan seksama, kemudian menuliskan katakata yang didengar sesuai dengan apa yang ada di rekaman tersebut. Setiap hasil wawancara dipisahkan masingmasing sesuai dengan data informan.

b. Setelah peneliti menulis hasil wawancara tersebut kedalam transkrip, selanjutnya peneliti harus membaca secara cermat untuk kemudian dilakukan reduksi data. Peneliti membuat reduksi data dengan cara mengambil dan mencatat informasiinformasi yang bermanfaat sesuai dengan konteks penelitian atau mengabaikan kata- kata yang tidak perlu sehingga didapatkan inti kalimatnya saja, tetapi bahasanya sesuai dengan bahasa informan.

c. Kemudian data tersebut diklasifikasikan ke dalam kategori-kategori tertentu. Setiap data yang sama lalu dikelompokkan. Peneliti benar-benar harus memilah mana data yang kurang valid karena kompetensi subjek dalam memberikan jawaban diragukan, mendialogkan data yang satu dengan yang lain dan sebagainya.

\section{Kategorisasi}

Kategorisasi berarti penyusunan kategori. Kategorisasi adalah upaya memilah-milah setiap satuan ke dalam bagian-bagian yang memiliki kesamaan
(Moleong, 2014:288). Peneliti melakukan proses kategorisasi dengan menyeleksi data yang sudah dipilah dan dipisahkan secara berkelompok sesuai dengan aspek kajian yang telah ditentukan.

\section{Penafsiran Data}

Setelah diklasifikasikan, peneliti melakukan pemaknaan terhadap data. Pemaknaan ini merupakan prinsip dasar riset kualitatif, yaitu bahwa realitas ada pada pikiran manusia, realitas adalah hasil konstruksi sosial manusia. Dalam melakukan pemaknaan atau interpretasi tersebut, peneliti dituntut berteori untuk menjelaskan dan berargumentasi (Kriyantono, 2014:196-198). Hasil penafsiran ini yang kemudian akan dianalisis untuk dapat ditarik kesimpulan.Peneliti dalam hal ini melakukan triangulasi data kepada informan tambahan yaitu 4 orang pasien Instalasi Rawat Jalan RSUP H. Adam Malik.Validitas data dalam penelitian ini menggunakan metode triangulasi sumber, yakni peneliti mencoba mengeksplorasi dan memeriksa kembali derajat kepercayaan suatu informasi yang diperoleh dengan cara; 1) mengeksplorasi data hasil pengamatan dengan hasil wawancara, 2) mengeksplorasi apa yang dikatakan dokter dengan apa yang dikatakan pasien, 3) mengajukan berbagai macam variasi pertanyaan, dan 4) peneliti juga melakukan triangulasi ketika peneliti bertindak sebagai keluarga pasien, pada saat mendampingi keluarga peneliti yang memang sedang melakukan proses pengobatan di RSUP $\mathrm{H}$. Adam Malik.

\section{HASIL DAN PEMBAHASAN}

Semua dokter yang menjadi informan dalam penelitian ini mempunyai pengalaman dalam melayani pasien yang berbeda budaya. Setiap hari mereka 
melayani pasien dengan latar belakang budaya yang beraneka ragam karena RSUP H. Adam Malik merupakan Rumah Sakit Tipe A dan pusat rujukan akhir, sehingga banyak pasien dari seluruh Sumatera Utara dan luar Sumatera Utara berobat di tempat ini. Budaya pasien yang paling sering mereka jumpai di RSUP H. Adam Malik adalah Karo, Batak Toba, Aceh dan Jawa.

Menurut sebagian besar informan keragaman budaya pasien bukanlah sebuah masalah, mereka sebagai dokter tidak pernah melihat pasien dari sisi budayanya melainkan lebih fokus kepada penyakit yang diderita pasien. Dalam proses pelayanan kesehatan dokter kepada pasien di RSUP H. Adam Malik terlihat bahwa jenis kelamin dokter dan pasien turut mempengaruhi pelayanan yang diberikan, dokter perempuan dalam penelitian ini cenderung lebih menyukai pasien perempuan, karena menurutnya sikap perempuan dalam menghadapi suatu penyakit lebih tenang sehingga memudahkan komunikasi, sementara dokter laki-laki justru lebih berhati-hati ketika melakukan pemeriksaan terhadap pasien perempuan, karena dokter menyadari ada kebutuhan yang berbeda antara pasien lakilaki dan perempuan, sehingga dokter berusaha untuk memberikan pelayanan berkualitas yang berorientasi kepada kebutuhan pasien.Sementara itu, pasien wanita terlihat lebih mampu mengutarakan keluhan-keluhannya kepada dokter daripada pasien laki-laki.

Berdasarkan hasil pengamatan dan wawancara mendalam yang peneliti lakukan, pasien laki-laki selalu menunjukkan bahwa mereka tidak lemah walaupun sedang dalam keadaan sakit. Mereka tidak pantas untuk terlihat lemah. Mereka tidak ingin diperlakukan seperti orang yang tidak berdaya.

Hal ini memperkuat pendapat dari Renata Schiavo tentang bagaimana gender mempengaruhi pemikiran seseorang tentang kesehatan dan penyakit. Schiavo menyebutkan bahwa gender merujuk pada peran dan tanggung jawab laki-laki dan perempuan dalam masyarakat dan keluarga mereka. Misalnya sesuai dengan pola perilaku yang diharapkan sebagai laki-laki, maka laki-laki dianggap tidak pantas memperlihatkan rasa sakit atau mempertunjukkan kelemahan-kelemahan serta keluhannya (Schiavo, 2007: 78).

Usia dan pengalaman dokter juga merupakan faktor penting dalam proses pelayanan kesehatan dokter kepada pasien. Kemampuan dokter dalam menghadapi pasien yang berasal dari beragam latar budaya turut dipengaruhi oleh usia dan pengalaman yang dimilikinya. Dokter muda dengan pengalaman bertugas yang masih sedikit cenderung lebih emosional dan tidak sabar dalam menghadapi pasien, sebaliknya dokter yang sudah bertugas puluhan tahun di RSUP H. Adam Malik terlihat lebih mampu menghadapi berbagai tipe pasien. Pengalaman bertugas selama puluhan tahun di rumah sakit membuat mereka kaya akan berbagai macam budaya pasien.

Dalam proses penelitian, peneliti juga mendapatkan hasil bahwa sebagian besar informan tambahan, memiliki rasa segan kepada dokter. Perbedaan dokter dan pasien dalam hal kelas sosial, pendidikan, sikap dan sebagainya menyebabkan komunikasi antara dokter dan pasien tidaklah pernah setara. Hubungan antara dokter dan pasien adalah salah satu hubungan interpersonal yang paling kompleks. Ini melibatkan interaksi antara orang-orang dalam posisi yang tidak setara, tidak sukarela, melibatkan isu - isu penting, sarat emosional dan membutuhkan kerjasama yang erat (Ong dalam Berry, 2007: 42).

Berdasarkan hasil observasi yang peneliti lakukan, kondisi ini mengakibatkan pasien cenderung takut untuk bertanya, takut untuk bercerita lebih banyak dan pada 
akhirnya hanya menjawab pertanyaan yang diajukan oleh dokter saja.

Sebagian besar pasien RSUP $\mathrm{H}$. Adam Malik merupakan pasien pengguna BPJS Kesehatan. Faktor situasional ini menyebabkan pasien harus menjalani serangkaian prosedur berobat yang cukup melelahkan. Mulai dari pengurusan rujukan berjenjang sebelum berobat, pengurusan administrasi di RSUP H. Adam Malik serta antrian berobat yang panjang karena banyaknya jumlah pasien pengguna BPJS.

Hal ini menurut peneliti juga mempengaruhi pelayanan kesehatan yang diberikan dokter kepada pasien. Jumlah pasien yang sangat banyak dan peraturanperaturan BPJS mengenai prosedur pemeriksaan kesehatan pasien sesuai kelas pertanggungannya yang mencakup banyak hal, seperti jenis tindakan yang boleh dilakukan, jenis obat yang boleh digunakan dan lain sebagainya, menurut peneliti sangat membatasi ruang gerak dokter dalam memberikan pelayanan kesehatan yang maksimal kepada pasien.

Semua informan utama menyebutkan mereka akan lebih mudah berkomunikasi dengan pasien-pasien lama yang sudah sering berobat di RSUP H. Adam Malik, karena dokter dan pasien sudah saling mengenal. Menurut para informan utama, suasana komunikasi seperti ini akan lebih santai dan lancar sehingga memudahkan proses pelayanan kesehatan.

Keseluruhan penjelasan diatas memperkuat pendapat dari Edelmann (Berry, 2007:40) yang mengemukakan bahwa sebagian besar pertemuan medis dapat dianggap sebagai interaksi antara dua budaya yang berbeda, yaitu budaya medis dan budaya pasien. Kedua kelompok ini memiliki pemikiran yang berbeda tentang kesehatan dan penyakit. Demikian juga dengan persepsi, sikap, pengetahuan dan agenda. Agenda pasien akan mencerminkan pengalaman unik mereka sendiri tentang penyakit dan ide-ide serta harapan mereka tentang konsultasi dan pengobatan, sedangkan penyedia layanan kesehatan akan mencerminkan pelatihan medis yang diperolehnya, serta faktor-faktor latar belakang pribadi.

Dalam proses pelayanan kesehatan dokter kepada pasien di Instalasi Rawat Jalan RSUP H. Adam Malik masih ditemukan hal-hal yang belum sesuai dengan Standar Prosedur Operasional yang ditetapkan Rumah Sakit. Upaya menciptakan hubungan yang baik dengan pasien di awal komunikasi masih sering gagal dilakukan.

Berdasarkan hasil wawancara kepada pasien dan triangulasi yang peneliti lakukan ketika ketika peneliti bertindak sebagai keluarga pasien pada saat mendampingi keluarga peneliti yang memang sedang melakukan proses pengobatan di RSUP $\mathrm{H}$. Adam Malik, ditemukan bahwa masih banyak dokter yang tidak mengucapkan salam, berjabat tangan dengan pasien dan memperkenalkan diri ketika melayani pasien. Durasi waktu yang diberikan para dokter untuk berkonsultasi masih dirasa kurang oleh pasien. Dalam penelitian ini, ada satu informan pasien yang mengaku memiliki waktu 30 menit ketika berkonsultasi dengan dokter. Setelah peneliti mencoba menggali informasi dengan mengajukan berbagai variasi pertanyaan, peneliti mendapatkan hasil bahwa durasi waktu 30 menit tersebut lebih banyak digunakan dokter untuk memberikan edukasi kepada pasiennya tentang penyakit yang diderita pasien. Hal ini menciptakan pemahaman yang baik dan kepuasan tersendiri bagi pasien tersebut.

Rata-rata waktu konsultasi yang didapatkan dari keterangan dokter dan pasien hanyalah 5-10 menit, durasi waktu ini sangatlah kurang terutama ketika dokter harus memberikan edukasi kepada pasien, sehingga pemahaman pasien akan 
pelayanan yang diberikan juga sangat minim.

Evaluasi atas respon pasien terhadap pelayanan yang diterima juga belum secara maksimal dilakukan. Dokter memang memberi kesempatan kepada pasien untuk bertanya sebagai respon dari tindakan medis yang diterima, namun masih banyak dokter yang memberi penjelasan kepada pasien hanya sekedarnya saja, minim informasi dan terkesan terburu-buru.Dalam memperoleh pemahaman atas informasi yang disampaikan pasien, para dokter yang menjadi informan dalam penelitian ini menggunakan berbagai macam sumber informasi, antara lain dari komunikasi verbal, non verbal, pemeriksaan fisik, status rekam medis pasien dan pemeriksaan penunjang yang diperlukan. Dan sejauh ini mereka mengatakan memiliki pemahaman yang cukup dengan memanfaatkan sumbersumber informasi tersebut. Pemahaman mereka akan komunikasinya dengan pasien dituangkan dokter lewat pengisian rekam medis pasien dengan benar, pemilihan prosedur diagnostik untuk pasien dan pemberian resep obat yang tepat.

Dokter memperoleh pemahaman atas komunikasi nya dengan pasien melalui interaksi dengan pasien baik secara verbal maupun non verbal. Semua informan utama berusaha menyesuaikan diri dengan budaya pasien guna menghasilkan pemahaman bersama. Cara-cara menyampaikan pesan yang dipilih para dokter disesuaikan dengan jenis kelamin, status sosial, usia, pendidikan dan kebutuhan pasien.Ketika peneliti mencoba untuk memeriksa keabsahan keterangan yang diberikan dokter seputar pemahamannya tentang informasi yang diberikan oleh pasien, para pasien yang menjadi informan tambahan menuturkan bahwa mereka yakin dokter paham atas informasi yang mereka sampaikan. Terbukti dari tindakan medis yang diberikan pada mereka tepat sesuai dengan penyakit mereka, obat yang diberikan sesuai dan hal ini diperkuat dengan kondisi sebagian besar dari mereka yang sudah hampir sembuh.

Selain kondisi fisik, semua dokter yang menjadi informan juga mengatakan bahwa ketika mereka berkomunikasi dengan pasien, faktor-faktor seperti gesture, ekspresi wajah dan kontak mata turut menjadi perhatian. Mereka mengatakan bahwa pasien harus dilihat secara keseluruhan dari atas sampai bawah. Semua data ini nantinya akan mereka gabungkan bersama dengan hasil pemeriksaan penunjang lainnya untuk penegakan diagnosa penyakit pasien.

Hal ini sesuai dengan definisi komunikasi nonverbal yang merupakan proses yang dijalani oleh seorang individu atau lebih pada saat menyampaikan isyaratisyarat nonverbal yang memiliki potensi untuk merangsang makna dalam pikiran individu (Lubis, 2014:118).Tubuh merupakan sumber utama pesan nonverbal. Pesan-pesan ini dikomunikasikan dengan penampilan umum, warna kulit, pakaian, gerakan tubuh, postur, ekspresi wajah, kontak mata, sentuhan dan parabahasa (Samovar, 2010: 339). Komunikasi nonverbal memainkan peranan penting dalam kehidupan manusia, walaupun hal ini seringkali tidak kita sadari.

Dalam penelitian ini ada beberapa hambatan antarbudaya yang dialami dokter dalam memberikan pelayanan kesehatan kepada pasien, antara lain:

1. Bahasa

Semua informan utama dalam penelitian ini menganggap hambatan antarbudaya yang paling sering muncul dalam pelayanan kesehatan dokter kepada pasien adalah mengenai bahasa. Banyak pasien yang mereka jumpai setiap harinya yang sulit berkomunikasi dengan bahasa Indonesia atau bahkan tidak bisa sama 
sekali, ada juga yang sulit berkomunikasi karena penyakit yang dideritanya.

Namun para informan cukup mampu sejauh ini mengatasi kendala bahasa tersebut dengan menggunakan keterampilan berbahasa yang mereka miliki, kalau memang ada bahasa pasien yang mereka tidak pahami, para dokter ini akan menanyakan langsung ke keluarga yang mendampingi atau ke perawat yang menguasai bahasa tersebut atau bahkan memanggil jasa penerjemah, karena RSUP H. Adam Malik sudah menyediakan jasa penerjemah dalam hal pelayanan kesehatan antarbudaya.

\section{Pengalaman}

Para dokter yang menjadi informan utama menyebutkan cara berkomunikasi dengan pasien yang berbeda budaya biasanya tergantung pasien yang dilayani, ada yang tidak bisa menggunakan kalimat baku, tidak bisa menggunakan bahasa atau istilah medis, dokter tidak bisa kaku dan suasana komunikasi nya pun sebisa mungkin tidak formal. Jenis hambatan ini terjadi karena setiap individu tidak memiliki pengalaman hidup yang sama sehingga setiap individu mempunyai persepsi dan juga konsep yang berbedabeda dalam melihat sesuatu (Lubis, 2014:5$8)$.

\section{Hambatan Fisik}

Berdasarkan pengamatan dan wawancara yang peneliti lakukan kepada beberapa pasien di Instalasi Rawat Jalan RSUP H. Adam Malik sebagi informan tambahan, durasi waktu dokter dalam melayani pasien biasanya hanya berkisar 510 menit, hal ini menjadi sebuah keterbatasan bagi para pasien dalam menyampaikan keluhan mereka. Walaupun pasien cukup memahami kondisi dokter yang sibuk karena jumlah pasien yang banyak, namun mereka tetap akan merasa lebih senang kalau saja diperbolehkan berkonsultasi dengan dokter dengan waktu yang lebih lama.

Hambatan fisik lainnya adalah faktor kelelahan yang dialami oleh kedua belah pihak, baik dokter maupun pasien. Jumlah pasien yang sangat banyak membuat dokter di RSUP H. Adam Malik harus menjalani aktivitas pelayanan kesehatan dengan intensitas yang tinggi setiap harinya.Demikian juga dengan pasien, prosedur berobat yang rumit dan waktu menunggu yang cukup lama, membuat pasien mengalami kelelahan setiap kali berobat di RSUP H. Adam Malik.

Selain itu, hambatan fisik berupa situasi dan kondisi lingkungan ketika berkomunikasi dengan dokter juga merupakan salah satu hambatan antarbudaya menurut para informan. Ruangan yang berisik dan panas, ramainya orang yang lalu-lalang dan luasnya RSUP H. Adam Malik tanpa disertai dengan petunjuk arah yang lengkap, juga merupakan hambatan yang sering mempengaruhi pelayanan kesehatan.

\section{Kompetisi}

Kompetisi juga merupakan hambatan antarbudaya yang ditemui dalam penelitian ini. Hambatan ini muncul apabila penerima pesan sedang melakukan kegiatan lain sambil mendengarkan (Lubis, 2014:8).

Berdasarkan hasil wawancara dengan pasien sebagai informan tambahan, ketika berkonsultasi dengan pasien, dokter sering mendegarkan keluhan pasien sambil melakukan aktivitas lainnya, seperti mengisi status pasien atau sambil memeriksa fisik pasien.

\section{Non Verbal}

Selain kondisi fisik, semua dokter yang menjadi informan juga mengatakan bahwa ketika mereka berkomunikasi dengan pasien, faktor-faktor seperti gesture, 
ekspresi wajah dan kontak mata turut menjadi perhatian. Mereka mengatakan bahwa pasien harus dilihat secara keseluruhan dari atas sampai bawah. Semua data ini nantinya akan mereka gabungkan bersama dengan hasil pemeriksaan penunjang lainnya untuk penegakan diagnosa penyakit pasien.

Ada kondisi di mana pasien mengaku paham dengan penjelasan dokter, namun ekspresi wajah dan gerak tubuhnya menyatakan sebaliknya atau menyatakan sehat namun wajahnya terlihat pucat. Jadi dalam hal ini dokter harus mampu menganalisis kondisi pasien baik secara verbal maupun non verbal. Demikian pula sebaliknya, komunikasi non verbal dokter juga menjadi hambatan dalam pelayanan kesehatan dokter kepada pasien.

Berdasarkan hasil observasi dan wawancara yang peneliti lakukan, gerakan badaniah dan parabahasa dokter merupakan hambatan yang sering dialami pasien. Dokter yang jarang menatap pasien ketika berkonsultasi membuat pasien merasa tidak puas. Intonasi suara dan kecepatan berbicara dokter ketika melayani pasien dapat mempengaruhi reaksi atau penafsiran pasien terhadap pesan.

Dari keseluruhan temuan dan hasil dalam penelitian ini memperkuat penelitian dari Richard M Perloff, Bette Bonder, George B. Ray, Eileen Berlin Ray dan Laura A. Siminoffn pada tahun 2006 yang berjudul "Doctor-Patient Communication, Cultural Competence and Minority Health: Theoretical and Empirical Perspectives" yang menyimpulkan bahwa pelatihan tentang kompetensi budaya mutlak diperlukan para tenaga medis terutama dokter, agar dapat memberikan pelayanan kesehatan yang optimal.

\section{KESIMPULAN}

Berdasarkan hasil temuan penelitian yang diperoleh dari penelitian ini, maka dapat ditarik simpulan sebagai berikut:

1. Proses pelayanan kesehatan dokter kepada pasien di Instalasi Rawat Jalan RSUP H. Adam Malik belum dilaksanakan sesuai Standar Prosedur Operasional yang berlaku. Kemampuan setiap dokter dalam menciptakan hubungan yang baik dengan pasien di awal komunikasi belum merata dan optimal, masih ada ditemukan dokter yang memberi penjelasan kepada pasien hanya sekedarnya saja, minim informasi dan terkesan terburu-buru. Karakteristik dokter dan pasien serta faktor situasional turut mempengaruhi pelayanan kesehatan dokter kepada pasien.

2. Dalam hal pemahaman atas informasi yang disampaikan pasien, para dokter menggunakan berbagai macam sumber informasi, antara lain dari komunikasi verbal, non verbal, pemeriksaan fisik, status rekam medis pasien dan pemeriksaan penunjang yang diperlukan. Pemahaman tersebut mereka tuangkan lewat pengisian rekam medis pasien dengan benar, pemilihan prosedur diagnostik untuk pasien dan pemberian resep obat yang tepat.

3. Hambatan antarbudaya yang dialami dokter dalam memberikan pelayanan kesehatan kepada pasien antara lain adalah bahasa, pengalaman, hambatan fisik, kompetisi dan hambatan non verbal.

4. Hambatan-hambatan antarbudaya tersebut sedikit banyak berpengaruh terhadap pelayanan kesehatan yang diterima pasien, namun tidak sampai pada masalah pemilihan tindakan diagnostik yang salah, pengaruhnya terlihat pada masalah tingkat kepuasan pasien terhadap pelayanan. Sebaliknya, hambatan-hambatan antarbudaya 
tersebut tidak berpengaruh terhadap diagnosa penyakit pasien karena penegakan diagnosa penyakit pasien bukan hanya tergantung pada komunikasi antara dokter dan pasien saja, namun ada faktor lain yang juga tidak kalah pentingnya yaitu pemeriksaan fisik dan pemeriksaan penunjang lainnya. Ketiga hal ini harus digabungkan dan disesuaikan sebelum akhirnya diagnosa ditegakkan.

Berdasarkan hasil penelitian yang diperoleh dari penelitian ini, maka peneliti memiliki beberapa saran sebagai berikut:

1. Pelatihan tentang kompetensi budaya mutlak diperlukan para tenaga medis secara umum, terutama dokter di RSUP H.Adam Malik, agar dapat memberikan pelayanan kesehatan yang optimal.

2. Para praktisi kesehatan terutama dokter dan perawat perlu meningkatkan kemampuan berkomunikasi dalam menangani pasien untuk menciptakan komunikasi yang efektif dalam proses pengobatan.

3. Pihak RSUP H. Adam Malik perlu membenahi prosedur berobat di Instalasi Rawat Jalan, mulai dari pendaftaran sampai pengambilan obat, agar pasien dapat memperoleh pelayanan kesehatan dengan lebih mudah dan tidak menunggu lama.

4. Pihak RSUP H. Adam Malik perlu menerapkan aturan yang jelas dan tegas mengenai prosedur rawatan, baik rawat jalan maupun rawat inap agar mampu menciptakan kebersihan dan kenyamanan berobat di lingkungan rumah sakit.

5. Perlu dilakukan penelitian lanjutan untuk melihat bagaimana pasien memaknai pengobatan yang diberikan berdasarkan perspektif budaya masingmasing.

\section{DAFTAR PUSTAKA}

Berry, Diane. (2007). Health Communication: Theory and Practice. New York: Open University Press.

Kriyantono, Rachmat. (2014). Teknis Praktis Riset Komunikasi. Jakarta: Prenada Media Group.

Littlejohn, Stephen W \& Karen A Foss. (2011). Teori Komunikasi. Jakarta: Salemba Humanika.

Lubis, Lusiana Adriani. (2014). Pemahaman Praktis Komunikasi Antarbudaya. Medan: USU Press.

Moleong, Lexy J. (2014). Metodologi Penelitian Kualitatif. Bandung: Remaja Rosda Karya.

Perloff, Richard M., Bette Bonder, George B. Ray, Eileen Berlin Ray and Laura A. Siminoff. (2006). Doctor - Patient Communication, Cultural Competence and Minority Health: Theoretical and Empirical Perspectives.American Behavioral Scientist Volume 49 No.6.

Roszandi, Dasril. (23 Desember 2013). Ketua MKDKI: Kami Tak Mengenal Istilah Malpraktek. Diakses tanggal 14 Maret 2016 dari https://m.tempo.co.

Samovar, Larry A., Richard E Porter \& Edwin R McDaniel. (2010). Komunikasi Lintas Budaya. Jakarta: Salemba Humanika.

Schiavo, Renata. (2007). Health Communication: From Theory to Practice. San Francisco: Jossey Bass.

Sugiyono. (2013). Metode Penelitian Kualitatif. Bandung: Alfabeta. 